\title{
Pollutant Removal and PCR-DGGE Analysis of Microbial Community Structural Changes in an Integrated Vertical-Flow Constructed Wetland
}

\author{
Fahui Nie, Yongxi Zhou, Rongrong Liu, \\ Zhanmeng Liu, Defeng Huang* \\ School of Civil Engineering and Architecture, East China JiaoTong University, Nanchang 330013, China
}

Received: 20 September 2015

Accepted: 3 January 2016

\begin{abstract}
In this study we measured changes in the $\mathrm{COD}_{\mathrm{Cr}}, \mathrm{TN}, \mathrm{NH}_{4}^{+}-\mathrm{N}, \mathrm{TP}$, and $\mathrm{DO}$ concentrations and the $\mathrm{pH}$ of different layers in an integrated vertical-flow constructed wetland (IVCW) treating eutrophic water. We also examined the composition and diversity of the bacterial community in the IVCW using PCR-DGGE. Our results showed that most of the contaminants were removed during sewage flow from the down-flow chamber to the up-flow chamber. The removal rates of TN, TP, $\mathrm{COD}_{\mathrm{Cr}}$, and $\mathrm{NH}_{4}^{+}-\mathrm{N}$ were, respectively, $63.7 \%, 66.7 \%, 72.2 \%$, and $67.9 \%$ in the down-flow; consequently, the $\mathrm{COD}_{\mathrm{Cr}}$ and $\mathrm{TP}$ concentrations of the effluent fell below $10 \mathrm{mg} / \mathrm{L}$ and $0.05 \mathrm{mg} / \mathrm{L}$. There were some common microorganisms and specific microorganisms in the different layers of the constructed wetland because of the changes in environmental factors and nutrient levels. The diversity of the bacterial community was highest in the upper layer of the down-flow system, and the similarity in the down-flow system was higher than that in the up-flow system. From the down-flow system to the up-flow system, the diversity of the bacterial community increased from 2.31 to 1.95 and the structural similarity gradually increased from $65.7 \%$ to $70.9 \%$. The higher complexity of the bacterial community in the upper layer of the constructed wetland may be supported by plant oxygenation, rhizodeposition, and litter accumulation.
\end{abstract}

Keywords: constructed wetland, scenic water, denaturing gradient gel electrophoresis, bacterial community diversity

\section{Introduction}

In recent years, constructed wetlands have been introduced for ecological wastewater treatment. They

*e-mail: 258689463@qq.com have both ecological and economic benefits because they can incorporate ornamental uses as well as entertainment, and they can integrate sewage purification into landscape ecology. Thus, cities can gradually address eutrophication of their rivers and lakes by treating the water in a scenic setting. Microbes are the main actors that consume nutrients and transform and mineralize organic matter in 
wetland systems, and the microbial population structure and activity directly affects the purification function of a wetland [1-3]. Constructed wetlands have been widely used in domestic sewage and industrial wastewater treatment. However, little research has focused on wetland treatment of low pollutant concentrations in eutrophic rivers and lakes; most studies have examined short-term treatment efforts. There is a lack of research regarding the matrix in low concentration pollutant removal, as well as treatments using plants and microbes and the effects of long-term pollutant removal. Recently, research into microbial populations has built on the traditional methods of isolation and culture in wetlands; because this method requires significant time and energy, the number of cultures is generally limited and cannot represent the entire population of microbial systems [4-5]. Moreover, due to the low concentration of pollutants in water, microbes tend to lack necessary nutrients in wetland systems aimed at water purification, resulting in a relatively small amount of microorganisms. Thus, analyses that rely on traditional methods of isolation and culture may not succeed.

Soil, sand, and gravel have been used in constructed wetland systems for a long time. These systems often cover too much area and have low purification efficiency, and therefore they are not suitable for areas with high population density that do not have large land areas available. Research into treatment of urban sewage using constructed wetlands shows that nitrogen and phosphorus are difficult to remove; for example, the removal of phosphorus is generally only $30-50 \%$. After a few years, the adsorption potential of the matrix becomes saturated with respect to phosphorus, and it begins to release excess phosphorus, which greatly restricts the ability of the wetland to purify the sewage. In contrast, the choice of zeolite and shale as matrix materials could maintain continuous removal. By using matrix particles with a higher capacity for physical adsorption and chemisorption of nitrogen and phosphorus, the phosphorus and nitrogen removal process could be made more efficient and more environmentally friendly, and it could have a longer functional lifetime.

We combined the PCR-DGGE technique with PCRamplified and denaturing gradient gel electrophoresis. We isolated the same length of PCR-amplified fragments as different sequences of denaturing gradient gel, and then characterized the diversity of the microbial community structure and the evolution of the population from a molecular level. Compared to traditional isolating culture technologies, this method was fast and able to reflect changes at an appropriate timeframe; thus, it is a powerful technique for analyzing the microbial community structure and function in water treatment systems [6-7]. Currently, the PCR-DGGE technique has been applied to a variety of studies of microorganisms in the sewage treatment process, but has not been used as often in wetland research [8-9].

This study examines integrated vertical-flow constructed wetlands treating eutrophic scenic water using PCR-DGGE technology to investigate the microbial community structure of the wetland substrate. We analyzed the degradation of pollutants through time, the location, number and brightness of the sample bands, and the diversity index and similarity coefficients of the population. We use these results to discuss the succession and change of microbial populations in the integrated vertical-flow constructed wetland system.

\section{Materials and Methods}

\section{Test Device}

The integrated vertical flow constructed wetland system (see Fig. 1) consisted of the down-flow system $(0.5 \mathrm{~m} \times 0.5 \mathrm{~m} \times 0.6 \mathrm{~m})$ connected to an up-flow system $(0.5$ $\mathrm{m} \times 0.5 \mathrm{~m} \times 0.5 \mathrm{~m})$; at the base of the connection, the down-

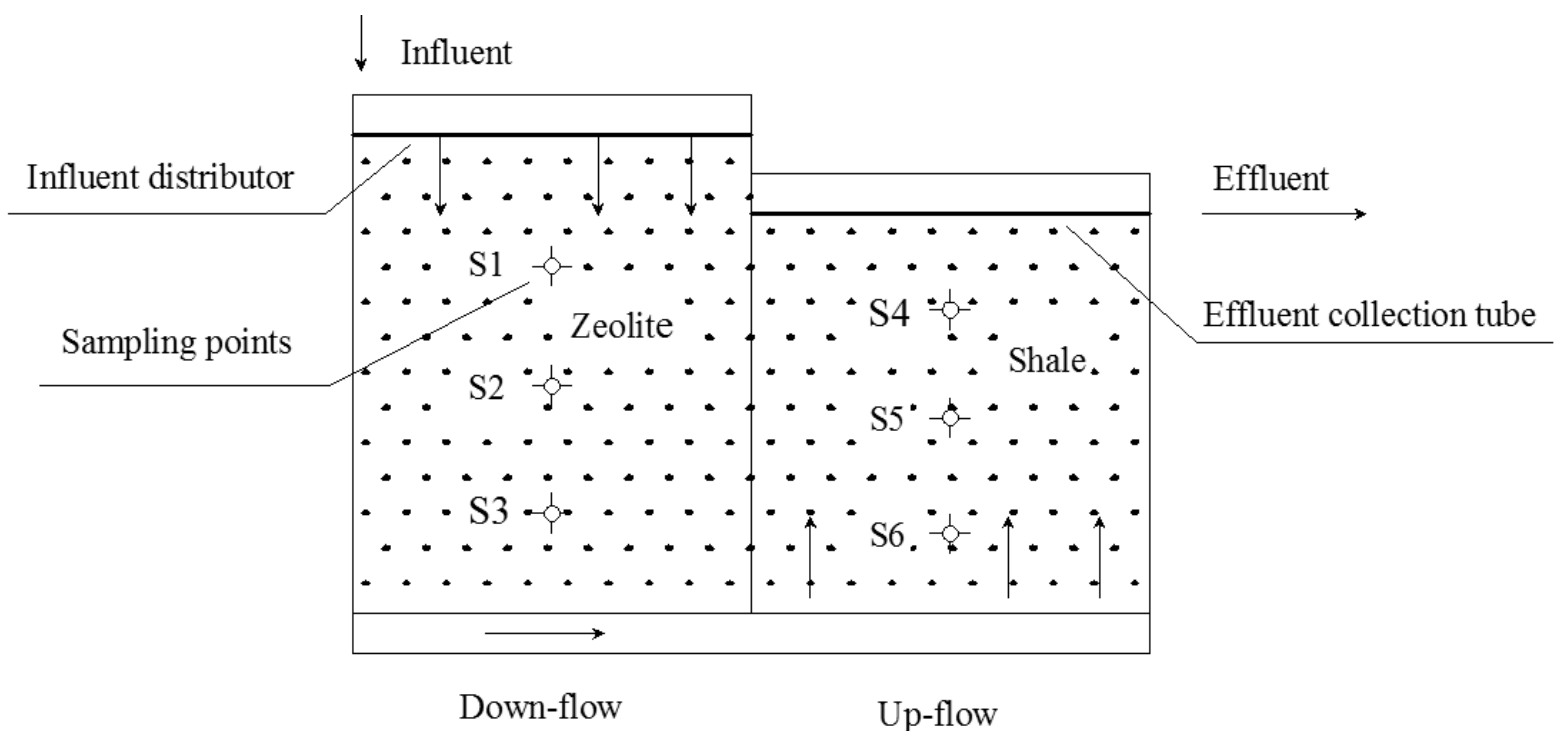

Fig. 1. Schematic diagram of IVCW. 
Table 1 . The primary mineral content of different substrates.

\begin{tabular}{|c|c|c|c|}
\hline Project & $\mathrm{SiO}_{2} / \%$ & $\mathrm{Al}_{2} \mathrm{O}_{3} / \%$ & $\mathrm{CaO} / \%$ \\
\hline Shale & 55.22 & 17.37 & 1.18 \\
\hline Zeolite & 67.28 & 13.55 & 2.64 \\
\hline
\end{tabular}

Table 2. The chemical composition of different substrates.

\begin{tabular}{|c|c|c|c|c|c|}
\hline Project & $\mathrm{Ca}$ & $\mathrm{Mg}$ & $\mathrm{Fe}$ & $\mathrm{Al}$ & $\mathrm{Si}$ \\
\hline Shale & 0.43 & 0.99 & 5.32 & 11.01 & 30.05 \\
\hline Zeolite & 2.40 & 0.26 & 1.20 & 6.64 & 31.51 \\
\hline
\end{tabular}

flow and up-flow were filled with a zeolite and shale matrix with a particle size of 3-5 $\mathrm{mm}$ to enhance the removal of nitrogen and phosphorus. The chemical content and the mineralogical variety of the zeolite and shale are shown in Tables 1 and 2. The surface layer of the down-flow system was laid with water distribution pipes, which connect to the surface layer of the up-flow system. The surface layer of the matrix was sown with the landscape plant Canna indica with a planting density of eight to 10 tubers $/ \mathrm{m}^{2}$.

The test water was taken from a typical eutrophication landscape pool on the campus of Tongji University. Water quality is shown in Table 3.

\section{Samples Collected}

The small-scale constructed wetland system was relatively stable and ran continuously for one year. Treatment began in the wetland two months after planting the reeds, which occurred in early April. Two months of stable operations with a hydraulic loading rate of $0.113 \mathrm{~m}^{3} /\left(\mathrm{m}^{2} \cdot \mathrm{d}\right)$ began in April 2013, according to monitoring of sewage flows to the inlet and the outlet water quality in the wetland system. Monitoring occurred from the surface layers of the down-flow to the bottom, then from the bottom of the up-flow to the surface; three

Table 3. Inflow water quality of the constructed wetland.

\begin{tabular}{|c|c|c|}
\hline Parameter & $\begin{array}{c}\text { Average } \pm \text { standard } \\
\text { deviation }\end{array}$ & Range \\
\hline $\mathrm{T}\left({ }^{\circ} \mathrm{C}\right)$ & $16.5 \pm 3.40$ & $9.80 \sim 23.30$ \\
\hline $\mathrm{pH}$ & $8.1 \pm 0.15$ & $6.93 \sim 8.45$ \\
\hline Turbidity $(\mathrm{NTU})$ & $29.4 \pm 3.93$ & $24.68 \sim 35.14$ \\
\hline $\mathrm{DO}\left(\mathrm{mg} \cdot \mathrm{L}^{-1}\right)$ & $2.39 \pm 0.43$ & $1.52 \sim 3.37$ \\
\hline Chlorophyll a $\left(\mathrm{mg} \cdot \mathrm{m}^{-3}\right)$ & $28.9 \pm 5.23$ & $20.82 \sim 36.24$ \\
\hline $\mathrm{COD}{ }_{\mathrm{Cr}}\left(\mathrm{mg} \cdot \mathrm{L}^{-1}\right)$ & $36.8 \pm 4.24$ & $28.03 \sim 41.76$ \\
\hline $\mathrm{TN}\left(\mathrm{mg} \cdot \mathrm{L}^{-1}\right)$ & $4.65 \pm 0.67$ & $2.38 \sim 5.59$ \\
\hline $\mathrm{NH}_{4}{ }^{+}-\mathrm{N}\left(\mathrm{mg} \cdot \mathrm{L}^{-1}\right)$ & $2.25 \pm 0.29$ & $1.52 \sim 2.73$ \\
\hline $\mathrm{TP}\left(\mathrm{mg} \cdot \mathrm{L}^{-1}\right)$ & $0.38 \pm 0.02$ & $0.18 \sim 0.52$ \\
\hline
\end{tabular}

sampling points with a uniform vertical distribution were established in the down-flow and the up-flow (Fig. 1). Samples were taken from both the water and the matrix, and contaminant analysis included examination of successional changes and degradation of the microbial population structure. The water samples were labeled from 1 to 6 , and matrix samples were labeled by depth, as follows: S1 (down-flow from 5-10 cm), S2 (down-flow from 20-25 cm), S3 (down-flow from 35-40 cm), S4 (upflow from $35-40 \mathrm{~cm}$ ), S5 (up-flow from 20-25 cm), and S6 (up-flow from 5-10 cm). Grab water samples were taken twice a month over two months (beginning in April 2013). All of the samples were analyzed for dissolved oxygen, $\mathrm{pH}$, temperature (T), turbidity (NTU), chlorophyll $a$, chemical oxygen demand (COD), total nitrogen (TN), ammonia nitrogen $\left(\mathrm{NH}_{4}^{+}-\mathrm{N}\right)$, and total phosphorous (TP). All water samples were analyzed in accordance with the Standard Methods for the Examination of Water and Wastewater [10].

\section{Pre-Treatment of the Matrix Samples and Extraction and Purification of Microbial DNA}

Pre-treatment included the following steps: after collection, the matrix samples were placed in a conical flask that had been sterilized. Next, $200 \mathrm{~mL}$ of sterilized distilled water were added and the samples were ultrasonically treated for $10 \mathrm{~min}$ and then shaken in a constant temperature shaker at a speed of $120 \mathrm{r} / \mathrm{min}$ for $30 \mathrm{~min}$. Finally, they were suspension centrifuged for $10 \mathrm{~min}$ at $8,000 \mathrm{r} / \mathrm{min}$, the supernatant was discarded, and the precipitate was collected and stored under refrigeration at $-70^{\circ} \mathrm{C}$ until it was used for DNA extraction.

We completed microbial DNA extraction using environmental samples from the $3 \mathrm{~S}$ column extraction kit (Shengneng Gaming Biotechnology Limited Company of Shanghai) to extract the total DNA sample. Next, we analyzed the samples using $0.8 \%$ agarose gel electrophoresis.

\section{PCR-DGGE Primer Sequences, the Reaction System, and Amplification Conditions}

PCR amplification primer sequences: we used bacterial $16 \mathrm{~S} \mathrm{rDNAV} 3$ variable region -specific primer pairs, namely GC-338F (5'-CGCCCGCCGCGCCCCGCGCCCGTCC CGCCGCCCCCGCCCGACTCCTACGGGAGGCAGC AG-3') and 518R (5'-ATTACCGCGGCTGCTGG-3') [11-12]. We then amplified the samples with a Mycycler (BIO-RAD) PCR. The amplified fragment length is approximately $250 \mathrm{bp}$, and we detected the fragments with $1.5 \%$ agarose gel electrophoresis.

The PCR reaction system involved constituting a $50 \mu \mathrm{L}$ PCR system, which used a template with $100 \mathrm{ng}$ of DNA, $5 \mu \mathrm{L}$ of $10 \times$ PCR buffer, $200 \mu \mathrm{mol} / \mathrm{L}$ of dNTP mix (with $10 \mathrm{mmol} / \mathrm{L}$ each), $15 \mu \mathrm{L}$ each of positive and negative primer for $20 \mathrm{pmoL}$, Taq enzyme $2.5 \mathrm{U}$, and doubledistilled water with no bacteria filled to $50 \mu \mathrm{L}$. 
The amplification conditions were as follows: denaturing at $94^{\circ} \mathrm{C}$ for $10 \mathrm{~min}$; denaturing at $94^{\circ} \mathrm{C}$ for $45 \mathrm{~s}$, annealing at $60^{\circ} \mathrm{C}$ for $45 \mathrm{~s}$, extension at $72^{\circ} \mathrm{C}$ for $45 \mathrm{~s}$, and 30 cycles; and final extension at $72^{\circ} \mathrm{C}$ for $10 \mathrm{~min}$.

\section{DGGE Gel Electrophoresis}

We used the D-Code System (BIO-RAD Co.) to analyze the amplified PCR products with denaturing gradient gel electrophoresis [13]. This process used $8 \%$ polyacrylamide gel $(\mathrm{V}$ (acrylamide) $/ \mathrm{V}($ bisacrylamide $)=37.5)$. The denaturing gradient range was from $35 \%$ to $60 \%$ (the denaturant contained $7 \mathrm{~mol} / \mathrm{L}$ of urea and $40 \%$ deionized formamide). The electrophoresis conditions were as follows: $1 \times$ TAE electrophoresis buffer which ran for $10 \mathrm{~min}$ at $60^{\circ} \mathrm{C}, 200 \mathrm{~V}$, and then ran for $4 \mathrm{~h}$ at $150 \mathrm{~V}$.

After electrophoresis, the gel was silver stained, as follows: first, it was fixed for $15 \mathrm{~min}$ in $10 \%$ acetic acid and a $30 \%$ ethanol mixture. Next, it was washed with deionized water for $5 \mathrm{~min}$ and then silver stained for 20 min with $0.1 \%$ silver nitrate. It was washed twice with deionized water for $5 \mathrm{~min}$ each, immediately immersed in colored liquid $(2.5 \%$ anhydrous sodium carbonate and $0.025 \%$ formaldehyde), and then slowly shaken to show clear bands. Finally, the stop buffer (consisting of 10\% glacial acetic acid and 30\% ethanol) was applied to the gel to stop the reaction. We used Bio-Rad Quantity One 4.6.3 software to analyze the samples, counting the number of electrophoresis bands and brightness after taking digital photos to evaluate the similarity and diversity of the microbial population.

\section{PCR-DGGE Fingerprinting Analysis}

We used the Shannon-Wiener index (H') to characterize the microbial community diversity index. H' may reflect the distribution of genetic diversity and difference both within the population and between populations. It is expressed as follows:

$$
H=-\sum_{i=1}^{S} \frac{n_{i}}{N} \ln \frac{n_{i}}{N}
$$

...where $S$ is the number of bands in each sample strip, $n_{i}$ is the number of individual species of $i$, and $N$ is the total number of individuals in the population (where the peak area was used to represent the number of individuals).

We used the pairwise similarity coefficient to compare the similarity between PCR fingerprints in the biofilm; the formula is as follows:

$$
C s=\frac{2 j}{a+b} \times 100
$$

...where $a$ represents the number of bands in a particular lane of a PCR profile, $b$ represents the number of bands in a different lane of the PCR profile, and $j$ represents the number of bands shared by the two lanes.

\section{Results and Discussion}

Changes in the Quality of the Pollutant Concentration and Other Physical and Chemical Parameters

First, we investigated the changes in the $\mathrm{COD}_{\mathrm{Cr}}$, $\mathrm{TN}, \mathrm{NH}_{4}^{+}-\mathrm{N}, \mathrm{TP}$, and DO mass concentrations and the $\mathrm{pH}$ of different layers in the integrated vertical-flow constructed wetland system (hereinafter referred to as the wetland system). This analysis helped us characterize the microbial community under various environmental conditions and nutrient levels in different parts of the wetland system, which helped us understand the process of community succession and change in the microbial communities. The changes in TN, TP, $\mathrm{COD}_{\mathrm{Cr}}$, and $\mathrm{NH}_{4}^{+}-$ Nmass concentrations in the wetland system are shown in Fig. 2.

Fig. 2 shows that the concentration of pollutants gradually decreased in the wetland system. Most of the contaminants were removed when the sewage flowed from the down-flow to the up-flow; pollutants were largely removed through the synergistic effects of the matrix, microorganisms, and plants. Consequently, the removal rates of $\mathrm{TN}, \mathrm{TP}, \mathrm{COD}_{\mathrm{Cr}}$, and $\mathrm{NH}_{4}^{+} \mathrm{-N}$ were, respectively, $63.7 \%, 66.7 \%, 72.2 \%$, and $67.9 \%$ in the down-flow. Organic matter is degraded by the actions of aerobic, anoxic, and anaerobic microorganisms, so the $\mathrm{COD}_{\mathrm{Cr}}$ concentration of the effluent was below $10 \mathrm{mg} / \mathrm{L}$. $\mathrm{TN}$ and $\mathrm{NH}_{4}^{+}-\mathrm{N}$ concentrations gradually decreased due to the effects of nitrification and denitrification, plant uptake, and adsorption by the matrix. TP concentrations also decreased in the wetland system because of the effects of adsorption by the matrix, as well as precipitation and absorption by plants in the wetland system. Furthermore, adsorption and precipitation was relatively complete with a longer HRT, so the TP concentration of the effluent was below $0.05 \mathrm{mg} / \mathrm{L}$.

To understand the effects of the environmental conditions during the degradation of pollutants, we analyzed water quality and determined the concentration

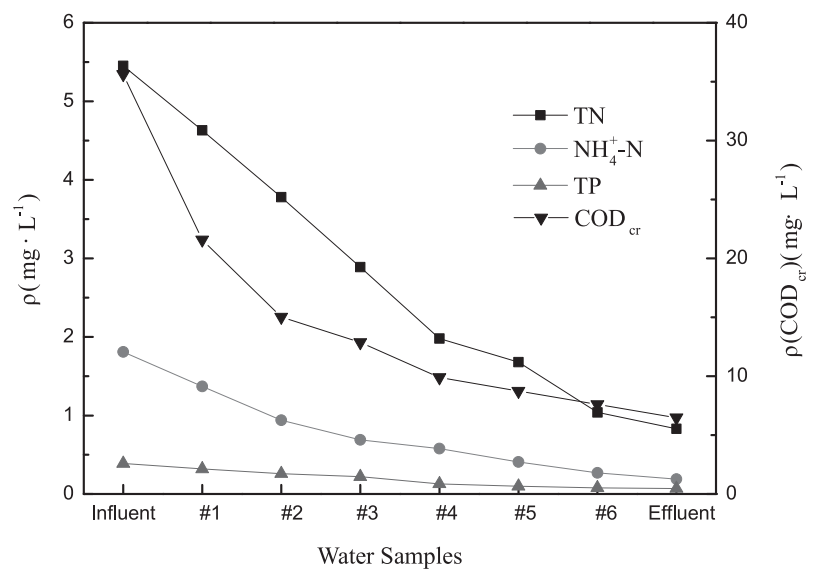

Fig. 2. Changes of pollutant mass concentrations in IVCW. 


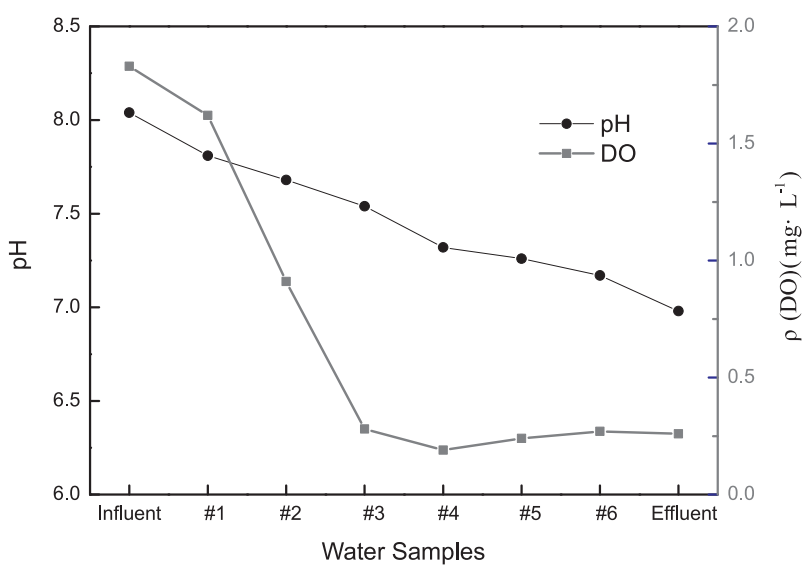

Fig. 3. Changes of DO concentration and $\mathrm{pH}$ in IVCW.

of DO and $\mathrm{pH}$ throughout the experiment; the results are shown in Fig. 3, which demonstrates that the physiological activity of microorganisms (such as nitrification) consumed DO, and the DO concentration of the landscape water entering the wetland system decreased as it flowed through, then increased slightly at the end. This may be due to the high initial mass concentrations of pollutants in the down-flow, and as the microbially mediated aerobic degradation of pollutants consumed more DO, the DO concentration dropped rapidly. Most contaminants were degraded between the down-flow and the up-flow; the concentration of pollutants was lower in the up-flow, where aerobic degradation slowed down and consumed less DO. Thus, because of the oxygen release from plant roots and atmospheric reaeration in the surface layer of the up-flow system, and the concentration of DO recovered modestly, which is consistent with previous results [14].

Fig. 3 shows that the $\mathrm{pH}$ at the inlet and outlet was 8.04 and 6.98 , respectively. The $\mathrm{pH}$ gradually decreased in the direction of flow, which is largely because of the acids produced by microorganisms in the process of pollutant degradation, along with the exchange and release from the matrix and the physiological activities of plants. Consequently, the acidity of the water in the wetland system increased and the $\mathrm{pH}$ of the effluent gradually reduced.

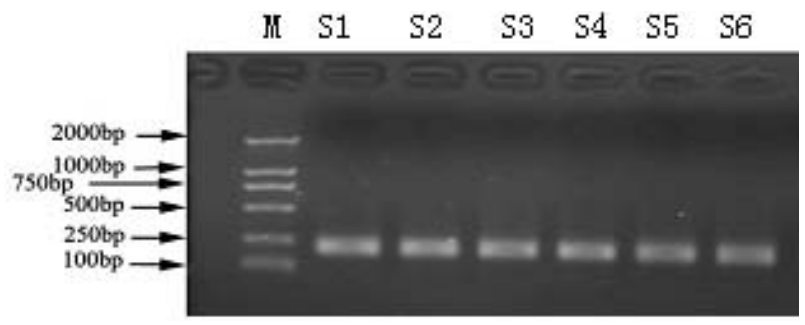

Fig. 4. V3 fragments of different substrate samples amplified by PCR.

\section{V3 Fragments of Different Variable Regions were Amplified by PCR}

We used the extraction and purification of total DNA from each sample matrix as a template, using the $16 \mathrm{~S}$ rDNA V3 variable region of most bacteria and archaeal. Along with the specific primer pairs $338 \mathrm{~F}$ and $518 \mathrm{R}$ in PCR amplification, we found a length of approximately 250 bp of DNA fragments (Fig. 4).

\section{Fingerprint Analysis of Microbial Communities}

The DGGE separation fingerprints of substrate samples at different locations in the wetland system are shown in Fig. 5. According to the separation principle of denaturing gradient gel electrophoresis, each band from the band spectrum of the polymerase chain reaction-denaturing gradient gel electrophoresis represents a possible bacterial taxon or operational taxonomy unit [15]. A larger number of electrophoretic bands indicates greater biodiversity, and a stronger band signal indicates a greater number of species. We determined the number and race relationships of the microorganisms at different locations in the wetland system and derived information about their microbial diversity.

Fig. 5 shows that the band locations, brightness, and number were not the same in the fingerprints of substrate samples at different locations in the wetland system. We suggest that these differences are mainly due to the difference in nutrient levels and environmental conditions. Each sample has three to four bands that appear brighter, indicating that a number of dominant species exist at different locations in the reactor. Some species in microbial communities only exist in specific ecological conditions, and when the environmental conditions change, the microbial species gradually decrease in dominance or

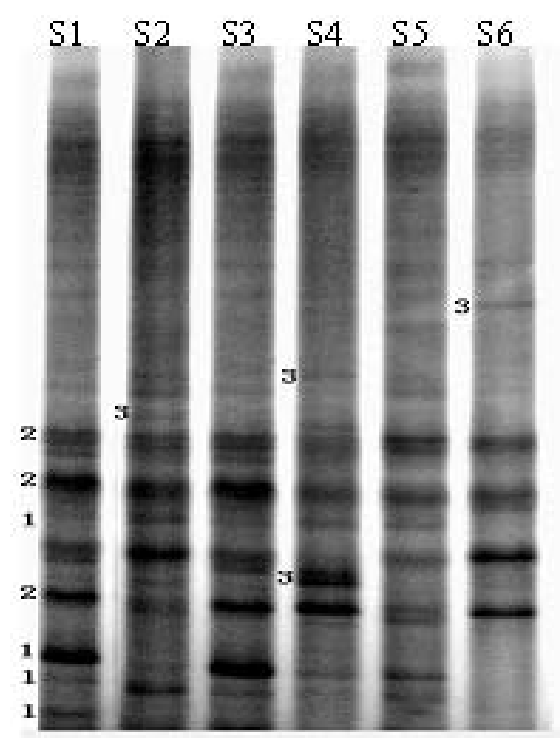

Fig. 5. DGGE fingerprints of different substrate samples in IVCW. 
Table 4. Matrix values of DGGE fingerprints for bacteria community in IVCW (\%).

\begin{tabular}{|c|c|c|c|c|c|c|}
\hline $\begin{array}{c}\text { Substrate } \\
\text { samples }\end{array}$ & S1 & S2 & S3 & S4 & S5 & S6 \\
\hline S1 & 100 & & & & & \\
\hline S2 & 66.7 & 100 & & & & \\
\hline S3 & 63.6 & 66.7 & 100 & & & \\
\hline S4 & 50 & 70 & 73.4 & 100 & & \\
\hline S5 & 60 & 63.2 & 70 & 77.8 & 100 & \\
\hline S6 & 55.6 & 58.8 & 55.6 & 62.5 & 72.5 & 100 \\
\hline
\end{tabular}

die out (as shown in band 1, Fig. 5). Another sample also shows a different number of bands at the same location (as shown in band 2, Fig. 5), demonstrating that the same species can exist in different numbers at various locations in the wetland system. Some species of microorganisms are highly adaptable in various environments and are pervasive in wetlands. Some species with wide ecological amplitudes play an important role in the microbial community by metabolizing substances and energy. Some samples showed new bands (for example, band 3, Fig. 5) in the matrix samples at different locations in the wetland system, indicating that when environmental conditions change, new microbial populations appear.

As shown in Table 4, as environmental conditions and nutritional levels changed in the direction of flow, the genetic distances among samples increased and the similarity decreased. For example, the similarity of S1 and $\mathrm{S} 2$ is greater than between $\mathrm{S} 1$ and other samples. Overall, the average similarity between down-flow and up-flow samples was $65.7 \%$ and $70.9 \%$, and the similarity between down-flow samples was lower than between upflow samples. This difference is mainly due to the larger changes in nutrient concentration, DO concentration, and $\mathrm{pH}$ of different layers in the down-flow, which resulted in more varied environmental conditions and nutritional levels for the microorganisms in S1, S2, and S3. Consequently, the microorganisms formed particular ecosystems in each set of environmental conditions, and each ecological system had its own microbial strains with

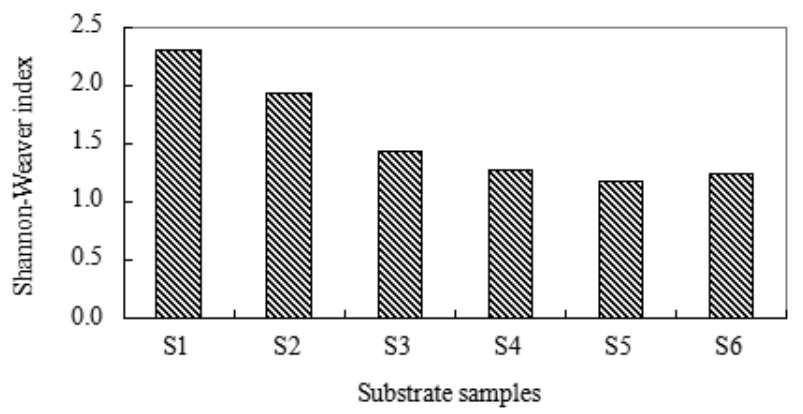

Fig. 6. The diversity index of bacteria community in constructed wetland. unique advantages, so the similarity was poorer among these samples. Because of the change in concentration of pollutants, $\mathrm{DO}$ and $\mathrm{pH}$ of the different layers in the up-flow system is smaller and there is a higher degree of similarity among the samples in the up-flow system, which had more similar environmental conditions.

\section{Analysis of the Diversity Index of the Microbial Community}

We used formula (1) to calculate the Shannon-Weaver index $\left(\mathrm{H}^{\prime}\right)$ of the matrix samples, as shown in Fig. 6, which indicates that there were obvious changes in microbial diversity in the wetland system along the direction of water flow. Specifically, the change in biodiversity of the microbial population was obvious in the down-flow system, where H' of S1 was the highest (2.31), and then H' reduced to 1.95 in the bottom of the down-flow system as HRT increased. Changes in the H' of the up-flow from the bottom to the surface layer were not as striking; $H^{\prime}$ varied from 1.28 to 1.22 .

The spatial variation in the microbial community structure was mainly due to the changes in environmental conditions and nutrient levels. Because of the higher concentrations of TN, TP, $\mathrm{COD}_{\mathrm{C}}, \mathrm{NH}_{4}^{+}-\mathrm{N}$, and DO in the surface of the down-flow system, as well as the unique spatial structure that allows for the growth of aerobic and facultative anaerobic microbes, the diversity of the bacterial community was greater. As the depth increased, the influx of organic carbon, nitrogen, and phosphorus sources was reduced and DO was consumed by the physiological activity of microorganisms. Thus, the reactor did not have enough organic substrate to support as much bacterial growth, and the diversity of the bacterial community decreased. The microbial populations in the wetland systems changed: aerobic microbes gradually disappeared in favor of facultative anaerobes, and this transition plays a major role in the degradation of pollutants. Similar to the environmental conditions in the up-flow system, the diversity of the bacterial community there was small.

Fig. 6 shows that the diversity of the bacterial community did not decrease as HRT increased in the upper layer of the down-flow system; instead, it was slightly higher in the middle to upper layer. This increase may be due to the density of plant roots in the upper layer; furthermore, the higher complexity of the bacterial community in the upper layer of the constructed wetland may have been supported by plant oxygenation, rhizodeposition, and litter accumulation. In particular, if the organic load was lower in the constructed wetland, the plant root zone could have boosted bacterial activity and caused microbial diversity to increase, which is consistent with previous results [16-17].

\section{Conclusions}

A. The concentrations of $\mathrm{COD}_{\mathrm{Cr}}, \mathrm{TN}, \mathrm{NH}_{4}^{+}-\mathrm{N}, \mathrm{TP}$, and DO plus $\mathrm{pH}$ decreased gradually along the wetland system 
due to the degradation and removal of pollutants by microorganisms and the physiological activity of plants. Contaminant removal mainly happened in the down-flow system in the constructed wetland.

B. The PCR-DGGE fingerprints of different microorganisms in the wetland system showed that as the environmental conditions changed from the surface of the down-flow system to the surface of the up-flow system, the original microbial species died out and new species emerged. Some common species of microorganisms existed in the different layers of the constructed wetland, and some distinctive species existed.

C. The diversity and the similarity of the bacterial community were greatly affected by vertical changes in the environmental conditions in the constructed wetland. The diversity of the bacterial community was higher and the similarity was lower because of the larger changes in the concentrations of $\mathrm{TN}, \mathrm{TP}, \mathrm{COD}_{\mathrm{Cr}}$, $\mathrm{NH}_{4}^{+}-\mathrm{N}$, and DO in the down-flow system. Because of the smaller changes in environmental conditions in the up-flow system, its mean genetic similarity was higher than in the down-flow system, but the diversity was lower in the up-flow system.

D. Plants improved the microbial diversity in the upper layers of the constructed wetland, possibly because of the effect of root system oxygenation, rhizodeposition, and litter accumulation.

\section{Acknowledgements}

The authors gratefully acknowledge the financial support of the Natural Science Foundation of China (project No. 51168031) and the Natural Science Foundation of Jiangxi, China (project Nos. 20114BAB213020 and 20122BBG70081).

\section{References}

1. RAGUSA S.R., MCNEVIN D., QASEM S. Indicators of biofilm development and activity in constructed wetlands microcosms. Water Res. 38 (12), 2865, 2004.

2. FU R.B., YANG H.Z., GU G.W., ZHANG Z. Analysis of Substrate Microorganisms Status in Constructed wetlands and Their Correlation with Pollutants Removal for Wastewater Treatment. Research of Environmental Sciences. 18, 44, 2005.

3. MENG P., PEI H., HU W., SHAO Y., LI Z. How to increase microbial degradation in constructed wetlands: Influencing factors and improvement measures. Bioresource technology. 157, 316, 2014.

4. VACCA G., WAND H., NIKOLAUSZ M., KUSCHK P.,
KÄSTNER M. Effect of plants and filter materials on bacteria removal in pilot-scale constructed wetlands. Water research. 39 (7), 1361, 2005.

5. WERKER A.G., DOUGHERTY J.M., MCHENRY J.L., VAN LOON W.A. Treatment variability for wetland wastewater treatment design in cold climates. Ecological Engineering, 19 (1), 1, 2002.

6. BALÁZS M., RÓNAVÁRI A., NÉMETH A., BIHARI Z., RUTKAI E., BARTOS P., KISS I., SZVETNIK A. Effect of DNA polymerases on PCR-DGGE patterns. International Biodeterioration \& Biodegradatio. 84, 244, 2013.

7. MAGDALENA K., THOMAS B., NARYTTZA N. DIAZB, ALEXANDER G., SEBASTIAN J., LUTZ K., DIMITRI MILLERA, KAI J. RUNTEB, PRISCA V., ALFRED P., ANDREAS S. Phylogenetic characterization of a biogas plant microbial community integrating clone library $16 \mathrm{~S}$ rDNA sequences and metagenome sequence data obtained by 454-pyrosequencing. J. Biotechnol. 142, 38, 2009.

8. XIA S.Q., JIA R.Y., FENG F., XIE K., LI H.X., JING D.F., XU X.T. Effect of solids retention time on antibiotics removal performance and microbial communities in an A/O-MBR process. Bioresource technology. 106, 36, 2012.

9. SHEN P.H., ZHANG J.Y., ZHANG J., JIANG C.J., TANG X.L., LI J.F., ZHANG M., WU B. Changes in microbial community structure in two anaerobic systems to treat bagasse spraying wastewater with and without addition of molasses alcohol wastewater. Bioresource technology. 131, 333, 2013.

10. APHA. Standard Methods for the Examination of Water and Wastewater, 19th ed'. American Public Health Association. Washington DC, 1995.

11. VARELA A.R., ANDRÉ S., NUNES et al. Insights into the relationship between antimicrobial residues and bacterial populations in a hospital-urban wastewater treatment plant system. Water research. 54, 327, 2014.

12. MOBARRY B.K., WAGNER M., URBAIN V., RITTMANN B.E., STAHL D.A. Phylogenetic probes for analyzing abundance and spatial organization of nitrifying bacteria. Applied and Environmental Microbiology. 62 (6), 2156, 1996.

13. ADRADOS B., SÁNCHEZ O., ARIAS C.A., BECARESD E., GARRIDOC L., MASC J., BRIXB H., MORATÓA J. Microbial communities from different types of natural wastewatertreatment systems: Vertical and horizontal flow constructed wetlands and biofilters. Water research. 55, 304, 2014.

14. HUANG J., WANG S.H., LUO W.G., LU Y. Influence of plant photosynthetic characteristics on DO distribution, purification effect in constructed wetlands. Acta Scientiae Circumstantiae. 26, 1828, 2006.

15. SU J.F., MA F., WANG H.Y. Application of PCR-DGGE to resolvemicrobial diversity in bio-ceramic reactor. Acta Scientiae Circumstantiae. 27 (3), 386, 2007.

16. IASUR-KRUH L., HADAR Y., MILSTEIN D., GASITH A., MINZ D. Microbial population and activity in wetland microcosms constructed for improving treated municipal wastewater. Microbial ecology. 59 (4), 700, 2010.

17. SI Y.M., LIU Y.J., WU Y.K, LI C.R. Different Wastewater Treatment Processes and Analysis of the Changes in Microbial Community Structure in It. Journal of Southwest University (in China ), 34 (8), 122, 2012. 
